\title{
Sowing time influence on the sweet corn productivity in the mountainous ecologically clean zone of Kabardino-Balkaria
}

\author{
Zalim-Geri Shibzukhov ${ }^{1, *}$, Alim Kishev ${ }^{1}$, Zalina Shibzukhova ${ }^{1}$, Murat Eziev $^{1}$, and Ilahun \\ Akbar $^{2}$ \\ ${ }^{1}$ Kabardino-Balkarian State Agricultural University named after V.M. Kokov, Lenin Avenue, 1V, \\ 360030 Nalchik, Russia \\ ${ }^{2}$ Xinjiang Agricultural University, No. 311 Nongda East Road, 830052 Urumqi, People's Republic of \\ China
}

\begin{abstract}
With a properly selected sowing time, the highest productivity of sweet corns is achieved. In the conditions of the mountainous zone of Kabardino-Balkaria, the timing of sowing sweet corn has not been studied, therefore, determining the optimal sowing time is one of the most important issues in the successful cultivation and obtaining high yields of sweet corn. In our studies, the sowing time influenced the survival rate of sweet corn plants. Optimal sowing favors the dynamic growth and development of plants, the root system, allows better assimilation of moisture in the soil, thus increasing the growth of green mass and the formation of larger and higher quality grains. Based on the analysis of data on the structure of yields, in all respects, the second sowing period (late April - early May) is ahead of other options, especially later sowing dates. The amount of products obtained depends on the weight of one earcorn. The number of marketable earcorns drops sharply at late sowing dates. The sharp decline in the productivity of sweet corn plants is explained by the fact that in the late sowing period, the soil moisture level is at a low level due to the rise in high temperatures.
\end{abstract}

\section{Introduction}

"Especially valuable for food use represents a grain of sweet corn in the phase of milky or milky-wax ripeness. In this regard, it is mainly grown for the canning industry, as well as for use in food in fresh, frozen and dried form" [1, 2, 3, 4].

"The cultivation of sweet corn is of great agronomic importance. Subject to high agricultural technology, it helps to clear the fields from weeds and is a good predecessor for grain crops, in particular for wheat" [7].

"Sweet corn is an economically profitable crop for farms. Its short growing season, especially of early ripening varieties, allows two crops to be grown in the same field during irrigation. It should also be noted that to obtain one ton of grain of edible corn using a

*Corresponding author: konf07@mail.ru 
technological complex of machines and herbicides, significantly less costs are required compared to other vegetable crops" $[5,7,9,11]$.

In mountainous areas, there have been no studies to determine the optimal timing for sowing sweet corn. The area occupied by this culture was so insignificant that no one has ever asked this question.

Therefore, to resolve this issue, we chose the topic of scientific work and set the following goals and objectives for its solution.

The purpose of the research: to identify the optimal time for sowing sweet corn in the mountainous zone of Kabardino-Balkaria for the highest yield of grain with the highest quality characteristics.

To achieve the goal, the following tasks were set:

- to determine the optimal sowing time in the mountainous zone of Kabardino-Balkaria;

- to study the effect of sowing dates on the productivity of sweet corn.

The scientific novelty of the work lies in the fact that for the first time in the mountainous zone of Kabardino-Balkaria in an ecologically clean area, the sowing dates for sweet corn plants were studied.

The practical value of the work. Recommendations based on the analysis of the data obtained will clarify the timing of sowing sweet corn and will be useful to agricultural producers.

\section{Research methodology}

The object of research is sweet corn of the Megaton F1 hybrid.

Agrotechnics on a test field are recommended for conventional corn in the area. The predecessor of sweet corn is winter rye.

The plot area was $100 \mathrm{M}^{2}$, the replication was fourfold.

Location of the study: mountain zone of Kabardino-Balkaria Baksan region, village Upper Kurkuzhin is located at an altitude of 850 meters above sea level.

Soil - typical black soil.

To solve the set tasks, studies were performed in the form of phenological observations, where the phases and dynamics of growth and development of sweet corn, plant density, plant survival, mass of the green part of plants, etc. were noted.

The yield of sweet corn was carried out on a plot, took by hand at $60-70 \%$ grain moisture. The data obtained were recalculated per hectare.

Mathematical processing of the obtained data was carried out according to the method of B.A. Dospekhova.

To solve the problems, the following sowing dates were determined for testing, based on the recommendation of literary sources for the cultivation of ordinary corn

1. I sowing date mid-April (April 15-25) - control;

2. II sowing date end of April - beginning of May (April 25 - May 05);

3. III sowing date mid-May (May 15-25);

4. IV sowing date end of May - beginning of June (May 25 - June 05);

5. V sowing date mid-June (June 15-25).

\section{Results and discussion}

With a properly selected sowing time, the highest productivity of sweet corns is achieved. In the conditions of the mountainous zone of Kabardino-Balkaria, the timing of sweet corn sowing has not been studied, therefore, determining the optimal sowing time is one of the most important issues in the successful cultivation and obtaining high yields of sweet corn. 
In our studies, the sowing time influenced the survival rate of sweet corn plants.

"Optimal sowing favors the dynamic growth and development of plants, the root system, allows better assimilation of moisture in the soil, thus increasing the growth of green mass and the formation of larger and higher quality grains" $[6,8,10]$.

An important indicator of crops is plant survival after germination and before harvesting. The future grain yield depends on the number of plants $[12,13,14]$. We found that the survival rate of sweet corn plants during the growing season depended on the sowing time (Table 1).

Table 1. Influence of sowing dates on plant survival, on average for 2019-2020

\begin{tabular}{|c|c|c|c|}
\hline \multirow{2}{*}{ Options } & \multicolumn{2}{|c|}{ Quantity of plants (thousand pcs / ha) } & \multirow{2}{*}{$\begin{array}{c}\text { Survival } \\
(\%)\end{array}$} \\
\hline & after germination & before harvesting & \\
\hline I sowing time $(\mathrm{k})$ & 65.5 & 62.4 & 95 \\
\hline II sowing time $(\mathrm{k})$ & 65.7 & 63.8 & 97 \\
\hline III sowing time $(\mathrm{k})$ & 65.4 & 62.2 & 95 \\
\hline IV sowing time $(\mathrm{k})$ & 63.6 & 58.7 & 92 \\
\hline V sowing time $(\mathrm{k})$ & 60.3 & 54.2 & 89 \\
\hline
\end{tabular}

As can be seen from the table, late sowing periods sharply reduce plant survival. The largest percentage of surviving plants was found at the 2nd sowing period, which amounted to $97 \%$ ( $2 \%$ higher than the control variant). The difference in the control variant with the lowest survival rate is $6 \%$.

Phenological observations of plant growth occupy an important place among studies. Based on the data obtained, the vegetation period of the plant is determined. According to our observations, at the beginning of the growing season, the growth phases in all variants of the experiment proceeded in the same way. Shoots appeared on the 10-15th day. Further studies have shown that the influence of the sowing time is clearly traced to the onset of the growth phases.

The results of a study on the effect of sowing time on the growth of green mass in sweet corn plants are shown in Table 2.

Table 2. Influence of irrigation regimes on the growth of green mass in sweet corn plants, $\mathrm{t} / \mathrm{ha}$.

\begin{tabular}{|c|c|c|c|c|}
\hline \multirow{2}{*}{ Options } & \multicolumn{4}{|c|}{ Day from the beginning of the growing season } \\
\cline { 2 - 5 } & 10 & 30 & 60 & 80 \\
\hline I sowing time (k) & 3.4 & 37.2 & 64.6 & 74.4 \\
\hline II sowing time (k) & 3.6 & 40.4 & 66.2 & 76.8 \\
\hline III sowing time (k) & 3.4 & 37.5 & 64.2 & 74.6 \\
\hline IV sowing time (k) & 3.2 & 35.4 & 62.1 & 70.7 \\
\hline V sowing time (k) & 2.8 & 28.5 & 56.3 & 63.4 \\
\hline
\end{tabular}

Analyzing the data in Table 2, it can be seen that the greatest increase in the green mass of plants of $76.8 \mathrm{t} / \mathrm{ha}$ was revealed in the second sowing period. At late sowing dates, the plants sharply reduced the productivity of green mass. The 5 th sowing period turned out to be poor for the accumulation of green mass and differed from the control variant by $11 \mathrm{t} / \mathrm{ha}$.

In our experiments, the sowing time significantly affects the grain yield (Table 3 ). As can be seen from the table, the yield and yield structure strongly depended on the sowing time.

Table 3. Influence of irrigation regimes on the yield and structure of the yield of sweet corn crops.

\begin{tabular}{|c|c|c|c|c|c|c|}
\hline Options & $\begin{array}{c}\text { Number of } \\
\text { marketable } \\
\text { earcorns } \\
\mathbf{1 ~}_{\mathbf{~ m}^{\mathbf{2}} \text { (pcs.) }}\end{array}$ & $\begin{array}{c}\text { A number of } \\
\text { granules on } \\
\text { the earcorn } \\
\text { (pcs.) }\end{array}$ & $\begin{array}{c}\text { Weight of } \\
\text { one } \\
\text { earcorn } \\
\text { (g) }\end{array}$ & $\begin{array}{c}\text { Grain } \\
\text { weight } \\
\text { from 1 } \\
\mathbf{m}^{\mathbf{2}} \mathbf{( g )}\end{array}$ & $\begin{array}{c}\text { Weight } \\
\text { of 1000 } \\
\text { grains } \\
\mathbf{g}\end{array}$ & $\begin{array}{c}\text { Weight of } \\
\mathbf{1 0 0 0} \\
\text { grains } \\
\text { (t/ha) }\end{array}$ \\
\hline I sowing time (k) & 5.8 & 594 & 396 & 894 & 295 & 9.1 \\
\hline II sowing time (k) & 6.3 & 607 & 408 & 997 & 311 & 10.3
\end{tabular}


Table 1. Continued

\begin{tabular}{|c|c|c|c|c|c|c|}
\hline III sowing time (k) & 5.7 & 584 & 389 & 845 & 287 & 8.8 \\
\hline IV sowing time (k) & 4.9 & 570 & 371 & 789 & 270 & 7.5 \\
\hline V sowing time (k) & 3.7 & 488 & 268 & 422 & 212 & 4.1 \\
\hline \multicolumn{7}{|l|}{ LCD $_{05}$} \\
\hline
\end{tabular}

On the control option, the yield in grain was $9.1 \mathrm{t} / \mathrm{ha}$, which is higher than other options except for the 2 nd sowing date. On the 2 nd sowing period, the yield was $10.3 \mathrm{t} / \mathrm{ha}$.

Based on the analysis of the data on the structure of the yield, in all respects the second sowing period is ahead of the other options, especially the later sowing dates. The amount of products obtained depends on the weight of one earcorn. The number of marketable earcorns drops sharply at late sowing dates. The sharp decline in the productivity of sweet corn plants is explained by the fact that in the late sowing period, the soil moisture level is at a low level due to the rise in high temperatures.

\section{Conclusions and recommendations for production}

In the mountainous zone of Kabardino-Balkaria, it is necessary to sow sweet corn at an early date.

Optimal dates for sowing sweet corn in a mountainous zone mid-end of April

The yield of sweet corn is highly dependent on the timing of sowing. So, a delay in sowing by $10-15$ days, the grain yield can decrease by $12-15 \%$.

For the successful cultivation of sweet corn in the mountainous zone of KabardinoBalkaria, we recommend sowing at the end of April.

\section{References}

1. I. M. Khanieva, Yu. M. Shogenov, Z.G. S. Shibzukhov, Materials of the international scientific and practical conference of the research centre "Povolzhskaya scientific corporation", 162 (2017)

2. Yu. M. Shogenov, Z. Gatazhokov, M. H. Khaniev, Grain farming, 3-4, 37 (2007)

3. Yu. M. Shogenov, Z. A. Ivanova, M. B. Khokonova, F. H. Nagudova, Science and Education - XXI Century, 2013, 41 (2013)

4. Yu. M. Shogenov, Z. S. Shibzukhov, S. B. Elmesov, T. S. Vindugov, Materials of the international scientific-practical conference dedicated to the year of ecology in Russia, 344 (2017)

5. A. Ezov, Z.-G. Shibzukhov, B. Beslaneev, Z. Shibzukhova, M. Khantsev, International Scientific and Practical Conference «Development of the Agro-lndustrial Complex in the Context of Robotization and Digitalization of Production in Russia and Abroad» (2020)

6. K. Nazranov, E. Didanova, Z.-G. Shibzukhov, M. Orzalieva, B. Nazranov, International Scientific and Practical Conference «Development of the Agro-Industrial Complex in the Context of Robotization and Digitalization of Production in Russia and Abroad» (2020)

7. M. S. Sidakova, E. N. Didanova, A. Y. Kishev, R. Z. Abdulkhalikov, International Scientific and Practical Conference «Development of the Agro-Industrial Complex in the Context of Robotization and Digitalization of Production in Russia and Abroad» (2020) 
8. Z.H. Khan, S.K. Khalil, Ali, M. Ikramullahe, A. Iqbal, B. Islam, K. Ali, W. Ali, M. Ahmad, S.G. Afridi, F. Shah, Fresenius Environmental Bulletin, 6568 (2019)

9. R. Mohi-Ud-din, N. A. Dar, L. Singh, Saba-Shafia, R. Jan, K. A. Khan, Vegetos, 459 (2017)

10. B. K. Mehta, F. Hossain, V. Muthusamy, R. U. Zunjare, J. C. Sekhar, H. S. Gupta, Indian Journal of Agricultural Sciences, 1543 (2017)

11. A. A. N. Franco, P. S. V. Filho, C. A. Scapim, R. S. Okumura, O. J. Marques, A. Y. Numoto, Australian Journal of Crop Science, 831 (2016)

12. K. Z. Berbekov, I. M. Khanieva, M. S. Sidakova, Materials of the I International Scientific and Practical Conference, 28 (2018)

13. L. Kh. Azubekov, M. Kh. Khaniev, I.M. Khanieva, Yu. M. Shogenov, International Scientific Research, 3(32), 158 (2017)

14. A. M. Temirzhanov, L. A. Andretsova, Materials of the International Scientific and Practical Conference, 36 (2020) 